\title{
WILLIAM SAVAGE, Iowa Proneer, Diarist, and Painter of Birds
}

(This is the diary of a naturalist and farmer who settled in the northeastern part of Van Buren County, Iowa, in 1855. Earlier installments appeared in the ANNaLs of October, 1933, January, 1934, and October, 1934.)

\section{[Continued from the October, 1934, number]}

July 12, 1861. Cut down a tree in branch, and shell corn and went to mill then went and borrowed Gill's spinning wheel and went to Masterson's after rolls.

13th. Had Mack's horse, Puss, and plowed my sorgo and potatoes, took her home and hoed some.

14th. Sunday. We all went to Sneath's.

15th. Went to Dr. Siveter's harvesting. Cut and bound wheat at Johnson purchase.

16th. Finished said purchase. P. M., cut wheat down by house.

17th. Cutting said wheat.

18th. Finished said wheat P. M., cut on wheat and oats in east field, I sick from 4 o'clock.

19th. Cutting and binding said oats.

20th. Cutting said oats, and I came home.

21st. Sunday. To mill and swim, and to Watson's mill with Joe E. Davis, then home and to Mack's oat bee at night.

22nd. To Salem. Binding oats.

2srd. A. M., bind oats. P. M., help Dr. in orchard, \&c.

24th. Dav and I hauled wheat and Samuel stacked it.

25th. Trim orchard, \&c.

26th. The same, all for Dr. Siveter.

27th. The same. At night went to Uncle William's and stayed there. 28th. Sunday. Came home. Took box honey off bees.

29th. Hoed my potatoes and some corn.

3oth. Hoed some and worked on Sol Gill's vest. Great excitement about Missourians being in Hillsboro. False alarm.

s1st. Hunting, Kill 2 pigeons. P. M., swimming and cut out my and Walter's pants.

August 1, 1861. Went to Gill riffle with Anna. She washed. Then work on brush fence. Very hot and dry.

2nd. Mow weeds and went to school. Last day. Cleaned out cistern and work on pasture fence.

srd. Work on fence an hour in morning. Samuel Siveter and Walter Shriner came here, and S. and I went up to Conley's, and then we went fishing. No rain yet. Corn dying with drought.

4th. Sunday. L. Wells and $\mathrm{I}$ at and in the ereek.

5th. Work on fence morning and evening. Midday, shell corn.

6th. To creek wth Anna washing, and on brush fence. 
7th. On brush fence, Gill's vest, and in swimming.

8th. On brush fence all day.

9th. Swimming, and then stayed in house while Anna went to creek. Worked on brush fence.

10th. Work on brush fence, and swim. Very hot.

11th. Sunday. Went to Wells's to borrow meal. Then the boys came and we went to creek.

12th. Fixed my pants and David Siveter came here. We went to Frame's field hunting. I killed 1 squirrel and 1 pigeon, P. M.

13th. Hunting in Frame's field. Kill nothing.

14th. Hunting early in morning in Frame's field. David killed 1, then I killed 1 turkey, the first this season. P. M., work on pasture fence.

15th. Went part way home with David. Coming home shot 2 turkeys at once. P. M., went to creek, Anna washed.

16th. Took 5 sacks to William C. Morris' to put my wheat in. Left them there for him to take 3 bushels of said wheat to mill. From there to Sigler's mill. Shot 1 fox squirrel. P. M., work on fence.

17th. Work on fence, and James Davis and I had a swim.

18th. Sunday. Early in morning went to Boley field and shot 2 turkeys at once, then L. Wells and I went bee hunting. Kill a woodchuck.

19th. Anna and I to creek washing. Thomas Siveter came here. I went to Wells's to borrow meal.

20th. Work on fence, and Tom and I went to creek swimming.

21st. Thomas and I went to Salem. I trade some. Stayed all night at Dr. Siveter's. Bought Nip, colt.

22nd. Went to Uncle William's. Mend 2 pairs pants for Dr. Siveter and left them there for Thomas to take home.

2srd. Shot 1 turkey at Uncle William's, then went home and went part way to I. Conley's to see about a wagon wheel. Not fixed, then went to Job Davis' and to Gill's about Millin. Mowed fence corners east.

2yth. Shell corn, cut weeds in corn, Went to Job's and work on pasture fence and went to W. E. Taylor's to look at Tarpley's colt.

25th. Sunday. Hunting, and partly painted a brant of Gill's. L. Wells came here.

26th. Kept hogs in yard for Tarpley Taylor. He did not come. Let them out, then cut weeds in corn. Then Anna went to the creek to wash. I cut a round coat for John Henry Masterson and one for Flanry Howard, both on cred.

27th. T. Taylor came and we made a trade provided Mack would give up his claim. Went to see Mack. He agreed and Taylor and I traded. I was to give him 10 shoats for a colt four months old, then work on pasture fence.

28th. Taylor came and got said shoats and I went and got said colt.

29th. Anna started to walk to Salem to stay a week. Left Walter and John at home. I work on said fence and close it up. P. M., rebuilt my hogpen and put 5 pigs in that got in Mack's field. 
30th. Did chores indoors and out and commenced portraying a bird Wayne Watson shot.

31st. Went to mill to see if they ground, then came back and took a sack of corn down, then finished said bird and went to mill and got my meal.

September 1, 1861. Sunday. R. Wells here. I wrote in book, \&c.

2nd. Finished making S. Gill's vest.

srd. Commenced my pants.

4th. Finished said pants. R. Wells came here and stayed all night and till noon.

5th. Anna came home in A. M. Uncle William came with her. She rode Bill, horse. P. M., I commenced cutting up corn. Set up 1 shock.

6th. We went to creek washing. P. M., cut corn and set up 2 shocks.

7th. Hunt in morning, and set up 4. shocks and kill 2 squirrels. P. M., fix my boot.

8th. Sunday. Put sheep in new pasture. John Savage here.

9th. Hunt in morning and kill 2 turkeys, 101/2 lbs., then cut corn and set 3 shocks.

10th. Cut corn, set 6 shocks.

11th. Cut corn and set 5 shocks. Shot 1 fox squirrel.

12th. Cut corn an hour, then in house. Anna went to creek to wash.

Then I went to John Turnham's to get whis' [whiskey]. He had none.

13th. Fix fence by bars. Hunt in morning. Cut corn 2 hours. Rained the first shower for a long time.

14th. A. M., cut corn, set up 4 shocks. P. M., went to Job Davis house. Raining.

15th. Sunday. Hunt in morning. Kill 1 fox squirrel, then wrote a letter, to J. Wetsel. L. Wells here.

16th. To mill, and set 1 shock corn, then it rained. Commenced a piece of fence west of sheep yard.

17th. Set up 3 shocks corn (hunt in morning), and finished said fence and put Snipcious colt in said yard.

18th. Hunt in morning. Cut corn and set 7 shocks.

19th. Hunt in morning cut corn, set 5 shocks.

20th. Hog in corn. Fix brush fence, and set 5 shocks corn,

21st. Hunt in morning. Cut corn, set 2 shocks. Finished said corn 48 shocks, except a patch for colt. Fix brush fence and went to mill and got meal, M. Sigler brought a wife home from Missouri.

22nd. Sunday. Hunt in morning. Killed 3 squirrels, then Samuel Davis came here. He and I hunted. Kill 2 squirrels each, then home.

23rd. Went to Gill's to see about my harrow then to Job's and from there home and cut out John Watson's coat and sew on same.

24th. A. M., had Job's horses and plowed a piece of ground south side of field and sowed fall wheat and grass and harrowed it in. Sam Veatch came here to get my name preparatory to a draft military. P. M., sewing on said coat.

25th. Rainy. Sew on same. William and Henry Hopper brought 2 
coats for me to make. Henry wanted his right off. Cut it out and sew on it.

26th. Sew on said coat. Eli Coddington came here to get volunteers. 27th. Finished Hen's coat, \$2.50.

28th. Finished John Watson's coat, \$2.00, Shot 1 fox squirrel and kill 2 rabbits.

29th. Sunday. Went to Job's, then back and did some writing for him.

30th. Went to Hillsboro, sold $33 / 4$ lbs butter at 8 ets., traded it out and $3 \mathrm{cts}$. Coming home shot a turkey $7 \mathrm{lbs}$.

October 1, 1861. Went to Conley's to see about sorgho making and from there to Hillsboro to rectify a blunder about L. Wells's caps, then to Wells's (rain), and from there home, and bladed some cane.

2nd. Went to Stanley's about said sorgho, and to Wells's to borrow $193 / 4$ lbs. meal, then home and strip cane and cut my buckwheat.

srd. Chink and plaster under sills of Job Davis' house, and carried boards in house (rain).

4th. Rain. Cut out Dr. Siveter's vest and sewed some on it, and to Wells's,

$5 t h$. Went to I Conley's and to Wells's fields, then home and sewed some, and strip cane, and set up buckwheat. Went to Con [ley's] lasses boiling at night.

6th. Sunday. Shot 1 squirrel. Anna and boys went to Wells's. I hunted some.

7th. Took $1 / 2$ bu. wheat to mill and brought back my meal, then stripped cane. In eve help Job Davis kill a 2 year old cow in return for his helping me kill 2 hogs.

8th. Strip cane.

9th. Finished stripping cane and topped some. P. M., hauled 1 load of wood for Job Davis and 1 for self. Went up to I. Conley's.

10th. Sewed on Dr. Siveter's vest.

11th. Hauled 1 load of cane for Job and 2 for self to I. Conley's. He agrees to make up my cane for $1 / 3$ and $I$ find wood.

12th. Finished Dr.'s vest and then went to Salem, took $51 / 2 \mathrm{lbs}$. butter $10 \mathrm{cts}$. Traded some and went to Dr.'s and stayed all night.

13th. Went to Uncle William's, and home in evening.

14th. Went to Job's and he and I hauled wood and cane, and wood for him. Help dig a cellar at night at I. Conley's, per Hen Bolley. Job boiled sorgho.

15th. Topping cane and binding blades.

16th. To Job's and help him cut and haul 2 loads of cane, then I cut and hauled 1 load for self and we ground sorgho and boiled all night.

17th. Haul 3 loads of cane and 1 load of wood to I. Conley's for self.

18th. Cut out pair of pants for Hen. U. Sneath and took them home. David Siveter came and brought Dr.'s pants and leggins. Hem 
said leggins. and he took them back. In P. M. help Andrew Simon's thresh wheat.

19th. A. M., help A. Simons thresh (not paid for). Finished at noon. P. M., went to mill and got corn ground. Shot 1 prairie chicken, the first this fall. Anna took Wells's meal home.

20th. Hard frost. Hunt and gather butternuts. Kill common partridge and a wood chuck.

21st. Cut and draw 1 load of wood to I. Conley's and 1 home, and sew some on Dr. Siveter's coat. Went to John Watson's mill.

22nd. Hunt in morning and kill 1 turkey at Carter bottom. Sewed some and help Job thresh.

23rd. Thresh for Job Davis. Finished at 2 o'clock. H. Sneath came here to sell me a quarter of beef and take pay in chopping and grubbing. Sewed on Dr. Siveter's coat.

24th. Sewing on said coat.

25th. Finished said coat.

26th. Took said coat to Salem and $41 / 4$ lbs. butter, 10cts. per P. M., sewed for Dr.

2yth. Sunday. David and I hunted. He killed 2 squirrels. I gathered a good mess of hickory nuts.

28th. Sewed most of the day for Dr., then went to Uncle William's (Rosa came there on Saturday). Went back to Salem with John and Tom and joined N. G., then back again.

29th. Came home. Shot a mink near the cut off, Carter's bottom and then dug potatoes.

soth. Finished potatoes and commenced digging cellar larger.

31st. Dug said cellar and went to mill. Mended my basket, put potatoes in cellar and measured Sam'l. Morris for a coat.

November 1, 1861. Thrashed my buckwheat and husked and shelled corn and took to mill. Went to Sigler's field.

2nd. Help Job Davis make a lime kiln. Haul 2 loads wood for self, and went to mill.

3rd. Sunday. Walter and I went butternutting. Thomas Savage came here to tell me they were going to Mount Pleasant next day. Went home with him that night.

4th. Went to Mount Pleasant with Tom and John. Bought a pair of boots, $\$ 2.50$, and 1 bushel salt, 75 cts., then back to Uncle William's.

5th. Came home and went to mill with Sneath, then made pen for little pigs and put some in, and fix Dr. Siveter's coat.

$6 t h$. Cut out and sewed some on Samuel Morris' coat.

$7 t h$. On the same, and kill 1 pig, guess $60 \mathrm{lbs}$.

8th. Finished said coat and cut out Dr. Siveter's pants.

9th. Sew on said pants.

10th. Sunday. Hunt some and sew on said pants.

11th. Husked and shelled corn and took it to mill and got it ground.

Took Gill's flour and molasses home. Carried up a shock of fodder, and cut wood. 
12th. H. Sneath 49 years old. I grubbed and chopped for him, and did the same the 13th, 14th, and the 15th.

16th. Went to Hopper's and got my 14. yards of jeans, then to schoolhouse and help fix it up for school. Went to Gill's to get his cattle to haul wood. He was gone away.

17th. Sunday. First snow. Went to Wiliam Turnham's with Job Davis after a calf.

18th. Grub some for Sneath.

19th. Thunder and rain. Sowed timothy seed. Went to Gill's shop and then sewed on Dr.'s pants and finished them.

20th. Grub for Henry Sneath, also the same the 21st and 22nd. (turned very cold), and the 23rd, to pay Henry Sneath for a hind quarter of beef.

24th. Sunday. Had Job's team and hauled 1 load wood. L. Wells here. Virgil Knowles borrowed my buck sheep. I cut out Job Davis' coat.

25th. Had Sneath's mare and went to Salem. Took $7 \mathrm{lbs}$, butter, $10 \mathrm{cts}$, per lb., traded some, and took Dr.'s pants, then went to Uncle William's and brought home my salt.

26th. Help Sneath kill a beef. James Stanley hauled my quarter home for me, then I took a copy of a note to I. Conley's for Samuel Siveter. Paid George Dawson $30 \mathrm{cts}$. due on traps. Cut up said quarter of beef, 127 lbs., 31/2 each.

2rth. Grub some poles for colt shed, and carry and set some.

28th. Grub, carry and set forks, and carry brush for the back and sides.

29th. Husk and shell corn, and cut a coat for Samuel Veatch, 30 ets., paid, and pants for Nathan Harlan, 25 cts., paid. Took a coat to make for N. Harlan and one for H. Morris, Sr. Finish shelling corn and took it to mill and got it ground.

30th. Grub and carry brush and fodder. Finish said shed, and haul 1 load of wood with Gill's oxen.

December 1, 1861. Second snow-2 inches. Went to Sigler field.

2nd. Cut out and sew on Dr. Siveter's drawers.

3rd. Vेery cold, more snow. Finish said drawers, and mend pants and fix to go to Salem.

4th. Went to Salem and back at night.

5th. Thunder and warm rain. Cut and sew on William Hooper's coat.

6th. Sew on same, and cut out a coat for Mathew Harlan, 30 cts., paid.

rth. Caught mink in pantry, small trap. Had Gill's oxen and haul one load wood. Cut coat for George Davis, 30 cts., paid, and finished Hopper's coat.

8th. Sunday. Hunt.

9th. Went to Job's, got a board to make part new bottom to my pork barrel, and to Gill's shop and made it. Then home and got hoop poles and partly hooped my barrel. Mrs. Wells here. 
10th. Finish said barrel and went to Wells's, and cut out Henry Morris' coat.

11th. Sewing on said coat.

12th. Killed 4 hogs and cut them up.

13th. Sew on said coat.

14th. Finish said coat in forenoon. S. Gill fixed my fire shovel and cold chisel, then I cut and hauled 1 load with his cattle.

15th. Sunday. Home in A. M., and hunt in P. M.

16th. Chopped some rail cuts and wood.

17th. Haul 2 loads wood with Gill's oxen, then to mill, and then grub.

18th. Grub, and cut out pants for Gill. Hunt in evening and sew.

19th. Grub and sew on said pants in evening.

20th. Same.

21st. Finished said pants and shell corn and went to mill and got it ground. Cut linings for my pants, and chop off some roots. Snow.

22nd. Sunday. Very snowy. Went to Sneath field. Shot 1 turkey weighed $181 / 4 \mathrm{lbs}$. $1 / 2$ past $2 \mathrm{P}$. M.

23rd. Had Gill oxen and hauled 2 loads wood and 1 of fodder.

24th. Chop wood and husk corn. Preparing to go to Uncle William's. Mack here. I went to Wells's and asked Lee to go with me to Uncle William's.

25th. Christmas. Lee and I went to Uncle William's early, then John, Tom, Lee and I hunted some. Lee and I kill 1 dove each. Stayed all night.

26th. We came home. Very cold.

27th. Fix shed and carry up and put brush on it, then hunt for sign on creek.

28th. Fix Gill's boot, then put a shoe on his sled and haul 1 load of wood to schoolhouse and 2 loads of fodder at home. He agreed to let me have the oxen to work if I will feed them.

29th. Sunday. Took oxen down home and turned them out. Hunt some and got the oxen.

30th. Haul 4 loads of wood and rails.

31st. Tom came here. Took corn and rye to mill. Haul 3 loads of wood and rails, and went to mill again and got said grist.

January 1, 1862. New Year's. We all went to H. Sneath's and home in evening with said oxen.

2nd. Haul 7 loads fodder.

srd. George Stanley had the oxen and I chopped 3 loads of wood.

4th. Watched Job Davis' field for turkeys. P. M. Fix Walter's shoes. G. Stanley brought the oxen back.

5th. Sunday. Put small blade in my knife and fix flute tube. Went hunting. Very snowy. Kill nothing. Commence black cat cap.

6th. Haul 4 loads wood and rails.

7th. Chop wood for Sol Gill.

8th. Split some 18 rails and chop wood for self. Put considerable snow in cistern. 
9th. Made John A. S. a pair of shoes, and went to Job Davis' to fix to go to Mount Pleasant.

10th. Job Davis, Hen Hopper and I went to Mt. Pleasant. I bought barrel salt, \$3.25, and sundries, amount, \$6.00. Very cold.

$11 t h$. Cut pair pants for William Masterson and took a coat to make for him,

12th. Sunday. Went to get the oxen, but did not, then chop some wood and set it up for self, and home.

13th. Had said oxen and haul 1 load wood for S. Gill and 1 for self, then I. Conley had the oxen. Very cold.

14th. Chopped wood and 9 rails for self on my land. Kill 1 rabbit.

15th. Kill 2 rabbits. Cut out coat for Wm. Masterson.

16th. Mrs. Sneath here. I mend my tick pants some.

17th. Mend tinware and gumption box. Went to my woods and clopped a load of wood and killed 5 rabbits, 1 quail and 1 blue jay. 18th. Went to I. Conley's and got the oxen and hauled 4 loads wood. 19th. Sunday. O. M. Wells and Mack Davis here. Home all day.

20th. Cut and sewed on Wm. Masterson's coat.

21st. To I. Conley's. Had oxen and hauled 6 loads fodder.

22nd. Sewing on said coat.

23rd. Finish said coat.

24th. Sam Siveter's son born. I. Conley and I went to Salem. Took 2 mink skins and left at F. Woodworth's for J. F. Paid Dr. Siveter interest up and $\$ 11.30$ on principal. Bought a washboard and 2 tin cups, 35 cts.

25th. Help Sol Gill load his goods on Conley's sled, then chopped some wood in my timber. At night Gill's chimney was pulled down and part of floor torn up.

26th. Sunday. Went to Wells's and then home. David Siveter and Course's boy here. I shot a common partridge, 1 g. squirrel and 2 quails. Snowing.

27th. Started up to Conley's. Met him and Gill and Gates going down to Gill's for some hogs. I went with them. Then had the oxen and hauled 2 loads of wood. Thawing some.

28th. Cut out and sewed on N. Harlan's coat.

29th. Awful cold. Shell corn. Went to Job's and then took corn to mill.

30th. Sew on said coat. We went to Union Baptist protracted meeting.

31st. Sewing. In evening to meeting.

February 1, 186\%. Chopped some wood. Caught 2 quails and 1 rabbit. Evening to meeting.

2nd. Sunday. Very cold. I went to Wells's and to meeting in evening.

3rd. Haul 2 loads wood with Conley's oxen, and took them down to him in timber. Evening, to meeting.

4th. Went to Gill's with oxen and S. Gill saw that part of his house 


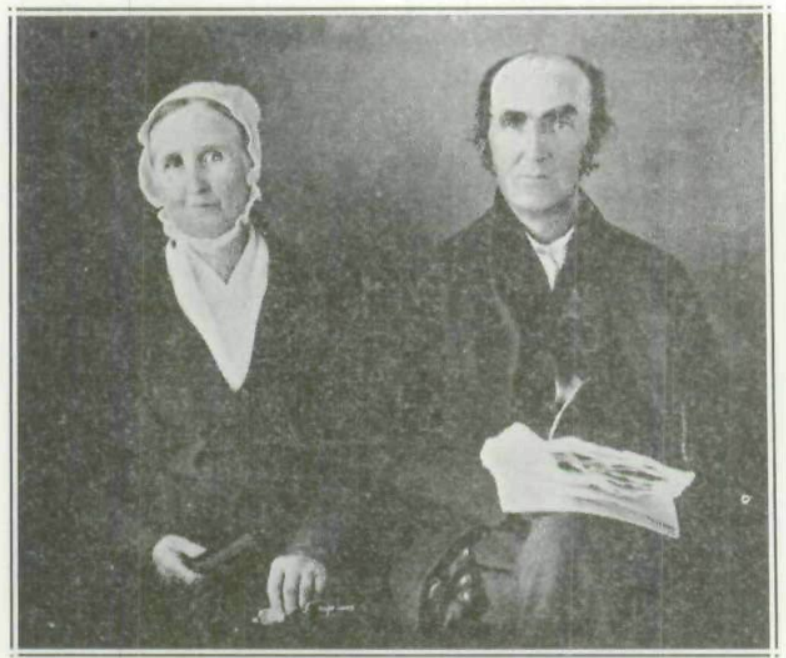

DOCTOR AND MRS. THOMAS SIVETER

(From a daguerreotype)

Thomas Siveter was born at Rowley, County of Stafford, England, December 22,1800 , attended village school, boarding school at Bennington, studied medicine at Dudley, matriculated at Edinburgh, and from that university received his degree, M. D. He married Miss Lydia Bridgewater of Birmingham in 1822, and came to America in 1823 . Landing at Philadelphia he went to Wilkesbarre, Pennsylvania, bought a small farm, lived there one winter, then sold it and returned to England. He remained in England until 1826 in what would be called an interneship at Bartholamew's Hospital, receiving a diploma that year from the Royal College of Physicians in London.

He returned to America in 1826, bought a home on Cayuga Lake shore. New York, entered the practice of medicine, but removed in 1835 to Ohio and settled on a farm near Bucyrus, remaining three years, then returned to New York state to a farm near Union Springs, practicing his profession. He removed to Salem. Iowa, about 1838, remaining there until his death which occurred July 6. 1893. He lived in Salem when its first brick house was built, practiced his profession among, and as, a Friend in a circle extending into Lee. Van Buren. and Jefferson as well as Henry counties, At its beginning in 1853 he was one of the managers of the lowa State Agricultural Society. He was always prudent in business, early acquiring much land which he resold to bona fide settlers such as William Savage, and remained a just, positive and helpful man without ostentation or excitement. He was often and familiarly referred to as "the sage of Salem." 
was torn down. Haul 1 load wood. Aunt Mary, Rosa, and John came here.

5th. Cut coat for G. Howard and took it home. Received 25 ets., and 30 cts. for Flan Howard coat. Went to G. Morris'. No money.

6 th. Went to John Turnham's and got 1 gallon whiskey, 50 ets.

$7 t h$. Had oxen and went to Hopper's after Masterson's flour, then the Masterson's and then to Hopper's, and then back to Masterson's and got it home. Haul 1 load wood and 1 of fodder.

8th. Fix salt barrel. Cut pants for Walter and John and chop some wood in my timber.

9th. Sunday. Handled 3 forks and 1 knife. P. M., Hunt some, trap 1 quail and shoot 2 squirrels.

10th. Chop aspen poles on Dr.'s land. At 1 o'clock, morning, boy Seth was born. Had Mrs, Davis and Mrs. Conley, Dr. Crell. Paid him $\$ 3.00$.

11th. Did home work and to Wells's after Walter.

12th. Cut Bub Gills' pants. Had Conley's oxen and hauled 4 loads of wood.

13th. Nothing but housework, \&c.

14th. Sew and went to Sneath's. Mrs. Sneath came home with me.

15th. Had oxen and haul 1 load wood and 5 of fodder.

16th. Sunday. R. and L. Wells here, and Sneath's wife here.

17th. Fix Walter's shoe.

18th. Went to Sneath's after clothes, Mrs. S. washed for us.

19th. About 12 in. more snow. Snowed all day. Mend my mittens. Now 8 o'clock and snowing yet fast.

20th. Had oxen and hauled 3 loads wood, \&c. Job Davis said he intended to seli a breachy estray ox and pay the owner if he comes. Milder.

21st. Fanny sheep had a b [black] lamb. Went to Job Davis' and shelled 3 sacks of corn.

22nd. A thaw. Torber sheep had a ewe lamb. Watch turkey bait, and to ereek. Kill 2 rabbits. Sam Siveter here.

2Srd. Sunday. Watch turkey bait. Not come. H. Sneath and wife here to dine.

24th. Went to Salem with I. Conley and James Wright. The latter traded 2 mules and harness, 2 3-year-old steers and 1 heifer to Dr. Siveter for his mortgage on Gills' 80 acres.

25th. Had Conley's oxen and chopped and hauled 3 loads of wood.

26th. Sewing. Mended Dr. Siveter's coat and went to Sneath's for clothes.

27th. Finished said coat.

28th. Haul and husk corn and chop wood, and went to Salem. Shot 1 fox squirrel.

March 1, 1862. Sewing at Dr. Siveter's, and came home. Got as far as Job Davis', and it being very dark and rainy $I$ fell over his wagon tongue and broke my gun lock guard off, and broke the breech plate above and below. Rain and sleet all day. 
2nd. Sunday. Snow all day. At home.

srd. To Job's and to Wells's. Got my traps I left there. Came home and sewed.

4th. Sew on my jeans coat, and help D. A. Cole, teacher, fix her school register.

5th. Sew and help Teacher Cole and finish my coat.

6th. Press coat off, and took Job's half bushel potatoes home.

$\gamma t h$. Two turkeys in my field. I chopped some wood on Dr.'s land. P. M., went to school, it being the [last] day.

8th. Had oxen and hauled 3 loads wood and 1 of fodder. Saw blue birds, first this spring.

9th. Sunday. Went to creek. Heard meadow lark. Biggest thaw yet. Water in cellar, dipped it out. Got the potatoes and mud out. Rinse them and put them in the house.

10th. Started for Wm. C. Morris'. Met him at A. Frazier's. He administered the oath of subdirector to me, then went to meeting of the board, then to Virgil Knowles and to mill. Traded 1 hog and a bunch of fodder to George Knowles for a musket.

11th. I husked said fodder, made a rod for and cleaned said gun, and fixed Walter's shoes.

12th. Saw ducks. Went to Wells's, took a letter to send to John Wetsel, then commenced fixing Dr. Siveter's coat.

13th. Sew on said coat. Went to protracted meeting. Thunder and rain which freezes on everything.

14th. Sew on said coat.

15th. Finish said coat. P. M., went to Carter bottom creek very high, and to Wells's. Kiill first squirrel with musket.

16th. Sunday. B. Wells' here, also Isaac Conley and wife. P. M., L. and R. Wells and I went to creek east.

17th. Chopped some wood on Dr. Siveter's land. Saw ducks in creek, then went to I. Conley's. He not at home.

18th. Had Conley's oxen and hauled 2 loads of wood, then Conley made the screw for the lock of said gun, and went to creek hunting.

19th. Rainy. L. and R. Wells here. I began L.'s dip net and R. run some bullets.

20th. Rain. Hunt on Carter bottom. Kill 1 duck, the first this spring. Snowing.

21st. Portrayed said duck.

22nd. Help Job Davis haul 2 loads wood and 1 of hay, he having a lame back and hand. I split some rails at home, then to Carter bottom.

23rd. Sunday. To meeting and down to branch.

24th. Chop wood for self.

25th. Fix brush fence and grub. Put sheep in pasture. Fix my boot, and went to Roberts mill to see about the boat.

26th. Pink heifer down sick. Bored her horns and went to Sneath's to try to get some turpentine, then home and grub.

[To be continued] 
Copyright of Annals of Iowa is the property of State of Iowa, by \& through the State Historical Society of Iowa and its content may not be copied or emailed to multiple sites or posted to a listserv without the copyright holder's express written permission. However, users may print, download, or email articles for individual use. 